\title{
The effect of prior compression tests on the plantar soft tissue compressive and shear elastic properties
}

\author{
Shruti Pai ${ }^{1}$, Paul T Vawter ${ }^{2}$, William R Ledoux ${ }^{1,2,3^{*}}$ \\ From 3rd Congress of the International Foot and Ankle Biomechanics Community \\ Sydney, Australia. 11-13 April 2012
}

\section{Background}

Changes in the shear plantar soft tissue properties with diabetes likely play a role in plantar ulceration, yet little is known about these characteristics. We recently conducted in vitro shear tests on specimens previously tested in compression to characterize the tissue under both these loading modes. However, previously tested specimens might not provide representative mechanical properties as prior testing may have altered the tissue. The purpose of this study was to test the effect of prior compression testing on the plantar soft tissue shear and compressive properties using paired specimens in a twopart study.

\section{Materials and methods}

Four pairs of cylindrical specimens $(n=8)$ were isolated per previous methods [1] from the calcaneus and lateral midfoot from three fresh-frozen, non-diabetic older cadaveric donors. In the first part of the study, one specimen from each pair was subject to compressive loading with modifications to compare properties before and after testing. In the second part, both paired specimens were subject to shear loading, i.e., both the previously compression tested from the first part and the previously untested specimens.

\section{Results}

The results (Table 1) of the first part demonstrated that prior compression testing affects the plantar soft tissue compressive properties by reducing peak stress and modulus by two to three times, although additional

\footnotetext{
* Correspondence: wrledoux@u.washington.edu

'VA RR\&D Center of Excellence for Limb Loss Prevention and Prosthetic

Engineering, Seattle, Washington, 98108, USA

Full list of author information is available at the end of the article
}

Table 1 Mean [SE] nonlinear elastic compressive and shear data parameters

\begin{tabular}{llll}
\hline & U & C & p $^{*}$ \\
\hline Peak compressive strain (\%) & $39.99[3.6 \mathrm{e}-3]$ & $39.98[6.7 \mathrm{e}-3]$ & 0.3 \\
Peak compressive stress (kPa) & $31.6[6.3]$ & $12.9[4.5]$ & 0.0002 \\
Compressive modulus (kPa) & $267[72]$ & $87[35]$ & 0.0031 \\
Compressive energy loss (\%) & $38.2[1.4]$ & $37.8[1.6]$ & 0.7 \\
Peak shear strain (\%) & $80.9[1.6 \mathrm{e}-2]$ & $80.9[1.6 \mathrm{e}-2]$ & 0.3 \\
Peak shear stress (kPa) & $9.0[1.5]$ & $9.9[2.0]$ & 0.6 \\
Initial shear modulus (kPa) & $58[19]$ & $61[16]$ & 0.8 \\
Toe shear modulus (kPa) & $5.4[0.7]$ & $5.3[0.9]$ & 0.9 \\
Final shear modulus (kPa) & $21.9[4.0]$ & $25.4[5.6]$ & 0.3 \\
Shear energy loss (\%) & $48.0[4.2]$ & $42.8[4.2]$ & 0.2 \\
\hline
\end{tabular}

$\mathrm{p}<0.05$ indicates significance for linear mixed effects regression; $U=$ previously untested, $\mathrm{C}=$ compression tested.

testing is needed since these results were likely confounded by stress softening effects. In contrast, in Part $B$, none of the elastic shear properties were affected by prior testing in compression.

\section{Conclusions}

This study demonstrates that prior compression testing of the plantar soft tissue may alter the compressive properties. However, since the shear parameters were not affected by prior testing in compression, shear tests using previously compression tested specimens should provided representative properties.

\footnotetext{
Author details

${ }^{1}$ VA RR\&D Center of Excellence for Limb Loss Prevention and Prosthetic Engineering, Seattle, Washington, 98108, USA. ${ }^{2}$ Mechanical Engineering, University of Washington, Seattle, Washington, 98195, USA. ${ }^{3}$ Orthopaedics and Sports Medicine, University of Washington, Seattle, Washington, 98195, USA.
} 


\section{Reference}

1. Pai S, Ledoux WR: The compressive mechanical properties of diabetic and non-diabetic plantar soft tissue. J Biomech 2010, 43:1754-1760.

doi:10.1186/1757-1146-5-S1-P14

Cite this article as: Pai et al.: The effect of prior compression tests on

the plantar soft tissue compressive and shear elastic properties. Journal of Foot and Ankle Research 2012 5(Suppl 1):P14.

Submit your next manuscript to BioMed Central and take full advantage of:

- Convenient online submission

- Thorough peer review

- No space constraints or color figure charges

- Immediate publication on acceptance

- Inclusion in PubMed, CAS, Scopus and Google Scholar

- Research which is freely available for redistribution

Submit your manuscript at www.biomedcentral.com/submit
() Biomed Central 